\title{
Maintaining Competence in the Initial Occupation: Activities among Vocational Teachers
}

\author{
Per Andersson $^{1}$ (D) - Susanne Köpsén ${ }^{1}$
}

Received: 8 July 2016 / Accepted: 5 October 2017 /

Published online: 25 October 2017

(C) The Author(s) 2017. This article is an open access publication

\begin{abstract}
Contemporary work-life changes rapidly, and vocational education and training (VET) teachers need to keep up-to-date with changing knowledge demands and technological developments. This article concerns VET teachers' continuing professional development (CPD) related to the specific vocations for which they teach. The aim is to analyse VET teachers' participation in various types of activities designed to make them become more knowledgeable in relation to industry currency. The study draws on a socio-cultural perspective on practice and learning. Theory concerning adults' participation in education is also used in analysing drivers of and barriers to participation in learning activities. The analyses are based on survey data from 886 Swedish VET teachers relating to their participation in different activities, barriers/ drivers concerning participation in these activities, perceived effects (outcomes) of participation in terms of professional development, and teachers' background. Reading professional texts was the most common CPD activity among those VET teachers participating in the study. Reading, and work in the VET teacher's former/initial occupation were the two activities where variation in performing them could be explained to the highest degree. The study particularly highlights the importance of boundary crossing between school and work-life for maintaining and developing the industrial currency of VET teachers' competence. Active membership and engagement in the community of practice of the initial occupation is important for participation in CPD activities closely related to this community.
\end{abstract}

Keywords Vocational teachers · Continuing professional development - Participation · Vocational areas · Variation

Per Andersson

per.andersson@liu.se

1 Department of Behavioural Sciences and Learning, Linköping University, 58183 Linköping, Sweden 


\section{Vocational Teachers' Continuing Professional Development in their Teaching and Training Subject}

Contemporary work-life changes rapidly, which presents challenges to vocational education and training (VET). VET teachers need to keep up-to-date with changing knowledge and technological developments in their teaching and training subjects. This article concerns VET teachers' participation in various types of activities to continue being knowledgeable in relation to industry currency and avoid professional obsolescence. Referring to the socio-cultural theory of learning (e.g. Lave and Wenger 1991) we assume the current vocational knowledge is situated in specific occupational practices, and to be knowledgeable means to be able and trusted to participate in these communities of practice. It is through active participation that learning and development occur. Thus, it is assumed that VET teachers' need of continuing professional development (CPD) to avoid obsolete occupational knowledge and skills varies with their involvement in current occupational practices. The need differs between countries due to the educational systems, with differences arising due to national traditions and culture (Brockmann et al. 2008a, b; Grollmann 2008). The organisation of VET, and what it means to be a VET teacher, differs between systems, with varying responsibilities for teachers in relation to school-based and workplace-based aspects of VET. Vocational education could be structured as workplace-based learning, integrated into everyday work, or as a dual system, where apprenticeship complements school-based courses. Vocational education could also be school-based, with an extensive integration of the vocational curriculum into vocational secondary schools. Furthermore, the 'vocational teacher' is not a clearly defined profession (Billett 2011; Grollmann 2008; Misra 2011). Thus, there are different views of vocational teachers' competence and professional development, and consequently, of vocational teachers' CPD. Despite the national differences, a general question is how VET teachers retain their occupation-specific expertise as e.g. a nurse or carpenter, having entered the profession of teaching, and what this means for the quality of VET. The conditions VET teachers face as they seek to develop industry currency are complex as current vocational knowledge is situated in specific work-life practices separated from the practice of school. For example, working part-time in school and in working life means the teacher faces conditions other than full-time work as a VET teacher. How school work is organised also influences teachers' opportunities to participate in their former occupational practice, e.g., the degree of VET teacher commitment in the students' periods of workplace-based learning. Thus, there are various conditions that affect VET teachers' demands and opportunities for occupational CPD. The need for industry currency is higher when they have full responsibility for students' workplace learning, as compared to when supervisors in workplaces have a formal and actual responsibility. Still, the industry currency of VET teachers' knowledge is a fundamental issue, regardless of the national conditions and requirements.

Our study concerns Swedish VET teachers at upper secondary level, who mostly have full-time or nearly full-time positions and are responsible for students' workplacebased learning even if it is guided by supervisors in the work places. Swedish VET is organised into 12 national three-year programmes, mainly school-based, though an alternative pathway of apprenticeship complements the ordinary 15 weeks of students' placements in working life. VET was reformed in 2011 and the current goals emphasise 
learning outcomes related to employability (Ministry of Education 2009). The reform increased the demand for VET teachers to keep up with the current industrial demands for vocational knowledge to ensure the quality of VET. Normally, VET teachers have studied in an equivalent VET programme and have work-life experience from the occupation related to their teaching subject. However, there are some VET programmes where the VET teachers have a qualification from higher education, e.g. licensed nurses who teach in the programme for assistant nurses.

Research concerning VET teachers' CPD is limited (see de Rooij, in Parsons et al. 2009, p. 92) and focuses mainly on their teaching competence (e.g. Bound 2011; Messmann and Mulder 2011). Hoekstra and Crocker (2015) note the significance of interaction between work-life and the educational context, as well as the need for investigation with this interaction in focus. The present study contributes to this area of research, with a particular focus on VET teachers' CPD related to the vocational subject and the currency of its content. Even though research with this focus is limited, there are some studies relevant to ours. Research mainly concerns conditions for CPD, rather than the processes of learning, which is in line with our study.

Vocational knowledge is the focus of Broad's $(2013,2015,2016)$ studies of how vocational teachers in English further education colleges maintain and develop their occupational expertise. Among 12 pre-defined CPD activities, reading books, journals, and online material turn out to be most common activities among the 57 respondents in this small-scale study. Of specific interest is the access to knowledge not 'codified' for use in VET. A range of activities that provide CPD experiences and where teachers are engaging with more or less 'tacit' or un/semi-codified knowledge are also included. These cover activities such as practicing, peer observations, shadowing, placements, involvement with professional bodies, and educational trips, but also inviting guest speakers, and attending courses and workshops (Broad 2016). Three key drivers for CPD are identified: a passion for the subject/occupation, maintaining occupational currency, and improving teaching and learning. Broad (2013) discusses how these drivers help teachers work hard even if there are organisational barriers. Thus, the main driver for CPD is to enhance knowledge and teaching, rather than to meet external requirements. Workload and funding are notable barriers. However, the main barrier seems to be the inadequate or 'impoverished' networks, which could also be a result of teachers' workload and lack of time (Broad 2015).

Lloyd and Payne (2012) have also shown that conditions of employment have an impact on the vocational teachers' opportunities to maintain the professional knowledge and skills related to their initial occupation. Having a part-time teacher position means it is possible to keep on working in the initial occupation. Established structures and management support are other conditions that have been shown to influence the vocational teachers' possibilities and motivations to move between the practice of school and the practice of work-life (Frisk 2014; Opetushallitus 2014). In a smallscale study, Fejes and Köpsén (2014) found various constraints for VET teachers' participation in work-life, which led to constraints for the teachers in maintaining the occupational knowledge needed to prepare the vocational students for work-life. They found VET teachers who did not maintain up-to-date vocational knowledge, and therefore were not competent to teach in the advanced courses of VET. To find out more about this part of VET teachers' CPD, further research has been conducted in Sweden. The present study is part of that research project. 
The first step of this project was an investigation of a new national initiative of CPD for vocational teachers, which provides them with the opportunity to participate in the >occupational community of practice of their teaching subject for some weeks, or in other, short industry arrangements (Andersson and Köpsén 2015; Köpsén and Andersson 2017). The results of the study indicated that vocational area and the geographical region in which the VET teachers are employed are conditions that influence the VET teachers' participation. Teachers from the areas of technology and construction were underrepresented among the participants, but with a comparably higher participation rate in industry arrangements among construction teachers. Teachers from highly populated municipalities were overrepresented, and the type of municipality was the strongest predictor for recurrent participation. These studies of VET teachers' participation in the national initiative raised new questions. In the second step, after the investigation of the national initiative, a survey study of the teachers' participation in various CPD activities was conducted, and in the third step, interviews with VET teachers were initiated. This article is based on the above-mentioned survey study.

The aim of this article is to analyse VET teachers' participation in different activities to develop vocational knowledge with industry currency and, thus, currency for today's VET teaching. The main research questions were:

- To what extent do VET teachers participate in CPD activities?

- How does participation vary between different vocational areas?

- To what extent can different factors explain participation in CPD activities?

These questions will be answered in the Findings section. The relevance of our quantitative findings for VET teachers' CPD will be discussed further in the final part of the article, in relation to prior research and our theoretical frame presented below. In particular, we will discuss CPD activities as 'boundary crossing' between different VET-related practices, the limitations and meaning of reading vocational texts for $\mathrm{CPD}$, and the variation in conditions for CPD between different local practices.

\section{Theoretical Frame}

The study draws on a socio-cultural perspective on practice and learning (Lave and Wenger 1991; Wenger 1998), with empirical findings focusing on learning through participation and boundary crossing. The situated character of knowledge is fundamental, and being competent to participate in a specific community of practice refers to having developed an identity, i.e. a membership of the community of practice, thereby being trusted and knowledgeable enough to be capable of engaging in the joint enterprise and using the shared repertoire of the community of practice. It is about having acquired the knowledge and competencies needed to understand and carry out the common goals of the community of practice, knowing how to solve work tasks, knowing what tasks are more important than others, and communicating with other professionals. Moreover, it is about having developed knowledge and understandings about how to use the shared repertoire of resources, symbols, language, and explicit as well as tacit values and traditions. 
It is through active participation in the community of practice that such development and learning is formed. However, a community of practice is not stable but changing; therefore, having a current identity, i.e. having current knowledge, understandings and skills, implies an active involvement in the community of practice.

It is through movements between different communities of practice, so-called boundary crossings, in landscapes of practice, that individuals learn and develop a nexus of identities (Akkerman and Bakker 2011; Wenger-Trayner et al. 2015). Following our theoretical framework, we argue it is through such boundary crossings that vocational teachers learn and shape their vocational teacher identity (Fejes and Köpsén 2014). This notion of identity in a framework of communities of teaching practice has also been used in a study of Canadian VET teachers (Farnsworth and Higham 2012).

We argue for the duality of a vocational teacher identity, as a VET teacher needs to be competent in teaching as well as in participating in today's occupational practice related to the teaching subject (Fejes and Köpsén 2014). Regarding the occupational practices related to the specific VET programmes, we consider the example of a carpenter. A carpenter needs to possess all the knowledge, understandings and skills to be trusted to be a member of and engage in the professional practice of carpenters. This includes to skilfully perform work tasks, to know how to communicate and cooperate with other carpenters, and to be capable of using and understanding the joint repertoire of resources, language, symbols, values etc. of that practice. The duality of the VET teacher identity is a prerequisite for teaching in VET. There is a need for vocational teachers to possess current work-life experience of the occupation related to their teaching subject in order to prepare the vocational students for work-life (e.g. Köpsén 2014; Robson et al. 2004).

Following this approach to occupational knowledge and VET teachers' competence, teachers' boundary crossing between work-life and school is significant for vocational education (Berner 2010; Vähäsantanen et al. 2009). They crossed the boundary between the practice of the initial occupation and the practice of VET when they became teachers. But they also benefit from crossing this boundary back and forth during their career as a VET teacher, to maintain and develop their knowledge. Thus, such boundary crossings are seen as essential for them to continue being competent in relation to the current occupational knowledge, understandings and skills of the subject they teach. Furthermore, it is likely that VET teachers also will update their occupational knowledge and skills through the use of various boundary objects, and participation in other communities of practice interconnected to the specific occupational community. For example, attending conferences and industry development arrangements, participating in various networks, reading journals, running development projects in schools, or studying in further education (c.f. Broad 2016). However, according to the theoretical perspective of situated knowledge and learning, which argues for learning through active participation in the community of practice, this way of learning might not cover all aspects of occupational knowledge, e.g., informal structures, rules and norms, or advanced and tacit skills.

In analysing data we also benefit from Cross's (1981) analysis of different factors, such as institutional, situational, and dispositional barriers, that may influence participation in adult education - or in our case CPD. Institutional factors are situated in the organisation of the VET schools, and in the work places for which pupils are trained. Situational factors refer to the life situation of the teacher, and dispositional factors concern the teacher's personal motivation. These factors may not only be barriers but also drivers that influence the extent of CPD activities. 
We draw on a holistic perspective on CPD, including all the activities in which teachers engage which are meant to improve their work, and that takes account of the influence of system factors (Bolam and McMahan 2004; Day and Sachs 2004). However, in the present study, we only investigate participation in activities that could help VET teachers to develop current vocational knowledge. In our study we also include all activities that could enhance knowledge and skills, even if not designed for this. Thus we also include activities not always described as intentional CPD - but which provide CPD experiences and influence the initial vocational competence and identity of the VET teacher.

\section{Methods}

This is a quantitative study, where a questionnaire distributed to VET teachers provides the main data for analysis. In this section we will describe the questionnaire development, the data collection and participants, and the data analysis.

\section{Questionnaire Development}

The analysis is based on survey data concerning vocational teachers' participation in eight different types of activities expected to provide CPD experiences, as well as on the perceived effects of these activities on the teachers, and perceived drivers of or barriers to participation. In addition to this, we use background, register data from Statistics Sweden, and supplementary background data collected in the survey.

The theoretical frame presented above means that we see learning through participation as central for VET teachers' development of their occupational identity, and this participation includes boundary crossings between various practices. This frame was employed to identify relevant variables to be included in the study, i.e. variables that could represent or explain participation in and boundary crossings between different communities of practice, and institutional, situational, and dispositional barriers to or drivers of participation. Participation was operationalized in items on eight separate types of activities possibly resulting in CPD experiences. These activities concern VET teachers' professional development, firstly in terms of boundary crossings between the practices of school and work-life, secondly as formal or informal studying/learning activities targeting the vocational subject knowledge, and thirdly in the development of how this knowledge is to be dealt with in their teaching practice. The activities are:

Relations to work-life through:

- Work in a work place or your own business.

- Study visits to work places.

- Coordination of students' placements or apprenticeship.

Vocational learning through:

- Participation in industry arrangements such as conferences, courses etc.

- Studying at university level, in formal adult education etc.

- Reading trade-related books, journals or magazines. 
Development activities:

- Projects, e.g. with industry representatives.

- Pedagogical improvement of cases, models, training stations etc.

These activities were identified based on our pre-understanding of possible CPD activities among VET teachers, derived from prior studies, our theoretical perspective, and dialogue with VET teachers during the development of the questionnaire. They are treated separately in the statistical analyses, as the questionnaire includes separate items for each type of activity. For each activity, three types of items were covered. Firstly, we asked in a number of items if and how often the teachers had performed these eight activities during the last two years. Secondly, there were items on the perceived effects or outcomes of the different activities. For each activity, six items concerned three types of effects - on vocational knowledge, on networks in the industry, and on teaching. All three were central CPD outcomes in relation to our theoretical frame. These outcomes include knowledge/learning as a central aspect of the occupational identity developed via participation, networks as important for boundary crossings between school and work places, and teaching-related effects as a result of boundary crossings back to school. Thirdly, there were items on perceived drivers/barriers related to each activity. There were eight items for each activity, concerning institutional, situational, and dispositional drivers/ barriers (cf. Cross 1981). For example, we asked about the importance of support from the school organisation and the way teachers' work is organised (institutional), about the teacher's family situation and the economic value in terms of income (situational), and about the personal interest and perceived need of developing occupational knowledge (dispositional).

There were also items concerning background data on teachers' vocational areas of teaching, and the length of experience in their initial occupations. The vocational area was included as different vocations have various types of vocational knowledge and practice as well as institutional contexts. The length of experience is a measure of previous participation in relevant communities of practice.

The questionnaire was developed by the researchers, in dialogue with VET teachers who gave feedback on the relevance of questions for the target group. The questions were finally checked by experts from Statistics Sweden, whose proposals improved the quality of the items.

\section{Data Collection and Participants}

The survey was distributed by Statistics Sweden to a representative sample of 2000 Swedish teachers working at upper secondary level. It could be answered using paper and pen or via the Internet. After two reminders, there were 982 answers, and among these, 886 are included in the findings, while the rest are overlaid. After correction for overlay, the response rate was $47 \%$.

The survey data were anonymized and supplemented with register data on teachers' background by Statistics Sweden. Register data employed in this article include 
information on sex, educational training, length of teaching experience, type of school, type of employment, extent of employment as a teacher, ${ }^{1}$ and the type of municipality where the teacher is active. Furthermore, as mentioned above, background data collected in the survey were included, concerning the vocational areas of teaching, and the length of experience in the initial occupation. Other background variables from the register data were included in the initial analysis but excluded when they had no significant influence on the logistic regression analyses. Excluded variables were age, type of school (publicly or privately owned), and type/level of training in the initial occupation. All background variables were selected to cover different aspects of the teachers' personal background as well as institutional and situational aspects of their present participation in landscapes of practice.

The comparison concerning teacher training includes three categories based on the register data: having a teaching degree, other teacher training, or no such training. The length of experience as a teacher and in the initial occupation was divided into three categories: $\leq 3$ years, 4-7 years, and $\geq 8$ years. The two types of schools were upper secondary school, targeting young pupils, and adult education, which provides upper secondary level vocational education for adults. The two types of employment status compared were permanent and fixed-term positions. The extent of employment as a teacher was categorised into four groups: <50\%, 50-75\%, 76-99\%, and 100\%. The geographical dimension, i.e., type of municipality in which a vocational teacher works, is described in four merged categories, based on an established categorisation of Swedish municipalities in ten groups or types among the 290 municipalities (Statistics Sweden 2011, p. 14): the main large city areas, the other large city areas, highly populated municipalities, and sparsely populated municipalities. We also compare six vocational areas targeted by vocational education at upper secondary level. We identified these areas from the 12 national vocational programmes (some small, local, options were also included in relevant categories). The six merged categories are: Care, Construction, Practical-aesthetical, Service, Technology, and Vehicles programmes. Here, it should be noted that a small number of teachers were teaching in more than one area, and in those cases they are included in more than one category.

Among the 886 vocational teachers for whom survey and register data were employed in the analysis, 437 were women and 449 were men. This means there was a higher proportion of women among the respondents than in the corresponding population of VET teachers in upper secondary school (49\% of the respondents, $38 \%$ in the population) (Swedish National Agency of Education 2015). The distribution of the teachers on the six vocational areas is presented in Table 1, which also shows that the respondents represent fairly accurately the population of VET teachers. The distribution concerning the other background variables employed in the analysis is presented in Tables 5, 6 and 7 in the Findings section. In a number of cases, information is missing for one or more survey items. The numbers of valid cases in the variables used in the analysis are presented in the tables.

\footnotetext{
${ }^{1}$ The extent of employment life spent as a teacher, e.g. $100 \%$ for those who work full-time as teachers, $50 \%$ for those who work half time as teachers.
} 
Table 1 Number and proportion of teachers teaching in the six different vocational areas

\begin{tabular}{llll}
\hline Vocational area & $\mathrm{N}$ & $\%$ of respondents & $\%$ in population \\
\hline Care & 151 & $17 \%$ & $15 \%$ \\
Construction & 98 & $11 \%$ & $14 \%$ \\
Practical-aesthetical & 193 & $22 \%$ & $19 \%$ \\
Service & 159 & $18 \%$ & $17 \%$ \\
Technology & 153 & $17 \%$ & $21 \%$ \\
Vehicles & 87 & $10 \%$ & $14 \%$ \\
\hline
\end{tabular}

The survey data include information on vocational area for 818 of 886 teachers. A small number reported teaching in more than one area; therefore, the total $\mathrm{N}$ in the table is 841 , as some of the 818 valid cases are represented in more than one category. \% of respondents is the proportion of the 886 teachers included in the analysis. \% in population is the proportion of all VET teachers in upper secondary school classified in the vocational area (Swedish National Agency of Education 2015)

\section{Data Analysis}

The dependent variables in the analyses are participation in each of the eight different types of activities. From the responses on participation we constructed a participation variable that described whether the informants had performed the activity at least every year, or more rarely. There is one exception - the activity Reading was so common that the group which had performed this more rarely than every year was too small for relevant statistical analyses. Therefore, the dependent variable for Reading describes whether the teacher has performed this activity at least every semester, or more rarely.

The indexes for perceived effects and barriers/drivers were constructed through grouping 14 items into six variables, three for effects and three for drivers/barriers, where the value of each variable, the index, is an average value (scale for effects 1-4; scale for barriers/drivers 1-5). The indexes cover perceived effects on the teachers' own vocational knowledge and skills, their teaching, and their networks in the industry, and institutional, situational, and dispositional barriers/drivers.

The exploratory analyses firstly include descriptive statistics, where significant differences have been identified through a chi-square test applied as a test of independence of distributions in cross-tables, and an analysis of variance applied concerning the distribution on the indexes. Finally, binary logistic regression analyses are presented to identify the relative influence of the different categories of the variables, while controlling for the effects of other variables. Here, the findings are presented as adjusted odds ratios, i.e. the likelihood of participation in one category, as compared to a reference category. Odds ratios above 1 mean that the likelihood is higher than for the reference category, and odds ratios below 1 mean a lower likelihood, e.g. an odds ratio of 2 means a double likelihood. The IBM software SPSS 23.0 was used for the analyses. Further statistical information is presented in each table in the Findings section.

As this is an exploratory study, we have even included indications of weak significance (+ indicates $p<0.1$ ) in the presentation of the findings. The motivation for this is that such differences could be of interest for further analysis, even if they did not turn out to be significant $(p<0.05)$ in the present study. 
It should be noted that there are limitations to the depth of analysis in a quantitative study targeting teachers' professional development. However, the focus of the present study is to analyse and explain patterns of participation in certain activities, and the survey identifies patterns in a broad group. The following interview study, which is part of the larger research project, will complement the quantitative results with deeper insights based on VET teachers' voices.

\section{Findings}

In this section we first present findings on the degree to which different categories of VET teachers participate in the various CPD activities, and how teachers' perceptions of effects and barriers/drivers vary depending on participation. The section will conclude with binary logistic regression analyses that identify the unique influences of the different variables on participation in each activity.

\section{Participation in CPD Activities - Variation between Vocational Areas}

The degree of participation in CPD, as operationalized in eight different types of activities, varies between these activities as well as between teachers from the various practices of different vocational areas (Table 2).

Reading is the most common activity - so common that we changed the comparison from performing it at least every year to performing it at least every semester (which explains why this activity does not have the highest figures in Table 2). Furthermore, the most common of the other activities is Study Visits, i.e. crossing boundaries to the practices of the different vocational areas, and the least common is Studying - a boundary activity in another educational practice than the practice of VET teaching.

There are a number of significant differences between teachers from various vocational areas, particularly concerning the boundary crossing activities Work and Industry Arrangements, where there are highly significant differences $(p<0.001)$. Both are more common among teachers from the practical-aesthetical area and less common among teachers in the technology area. Work is also less common in the area of care, and Industry Arrangements is more common in the construction area. These two activities, with the most significant differences between vocational areas, are also activities that are situated in specific practices of these areas. Furthermore, technology teachers also have a significantly lower participation rate for Reading and Development Projects, while practical-aesthetical teachers have a significantly higher participation in Development Projects, and care teachers read significantly more.

There are also some indications of a weak significance $(p<0.1)$ in that teachers in technology arrange fewer Study Visits and study less, teachers in construction and care do more work with students' placements, teachers in service participate less in Industry Arrangements, and teachers in construction read less.

\section{Other Factors Explaining Participation in CPD Activities}

The further analysis includes a number of variables - based on register and survey data - where we can see a variation in participation in the different activities. 


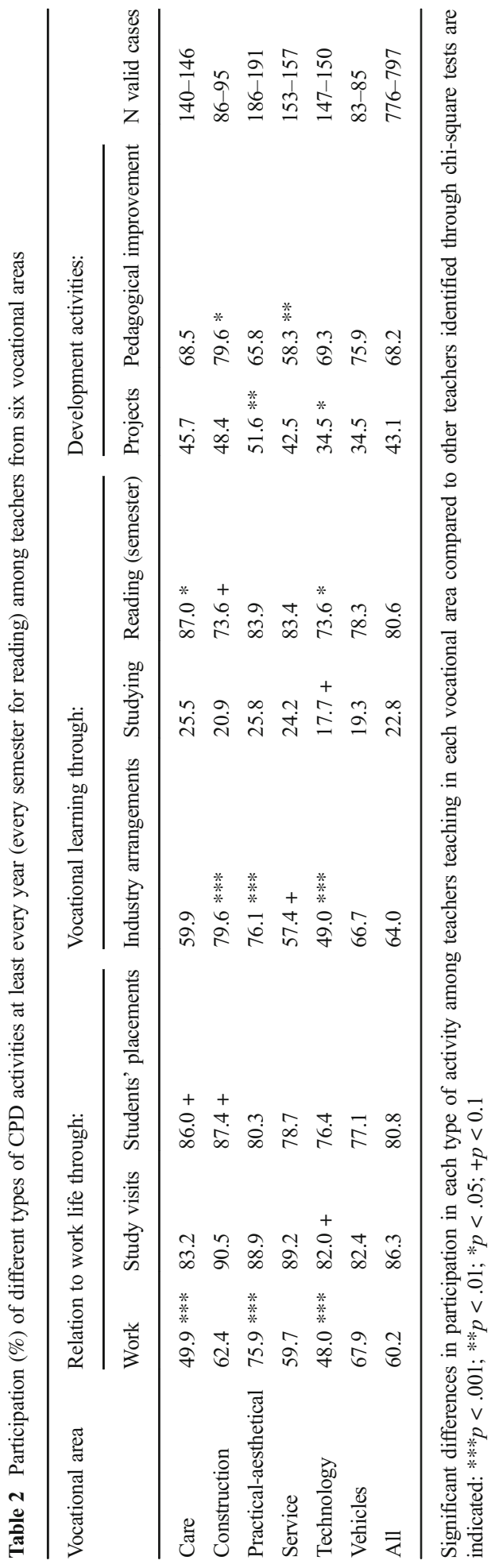


There are few significant differences between men and women (Table 3). The only significant differences concern higher rates for Studying and Reading among female vocational teachers. However, the participation rate is higher for women in four of the other six types of activities too, but among those it is only work with placements that shows an indication of a weak significance $(p<0.1)$. It is only the activities Work and Pedagogical Improvement that show somewhat higher rates among male teachers, with a weak significance $(\mathrm{p}<0.1)$ for the latter.

The indexes for perceived effects and barriers/drivers (Table 4), based on survey data, show a number of significant differences between teachers with higher/lower participation rates. In all cases but one, the average index is higher for those who have performed the activity at least every year (every semester for Reading) than for those who have not, and in many cases the differences are significant. The most outstanding activities here are Work, arranging students' placements, and doing Development Projects. Thus, there is a clear difference with higher perceived effects as well as stronger drivers, among teachers performing the activities more regularly.

Three variables that cover educational and vocational background indicate the formal educational competence and the length of experience in the teaching practice and in the practice of the initial occupations (Table 5). The comparison concerning teacher training shows highly significant differences concerning work and studying, which teachers with a teaching degree do to a lesser extent than other teachers. Furthermore, there is also a significant difference concerning Industry Arrangements, which those without teacher training, or with a formal teaching degree, participate in to a higher degree than those with some other form of teacher training.

The variation in teaching experience results in significant differences concerning firstly Work in the initial occupation, and secondly Studying. In both cases, teachers with longer teaching experience participate in the activities to a lower degree than those with shorter experience. There is also a weak significance $(p<0.1)$ for the difference in doing development projects, which is more common among teachers with mediumlong experience (4-7 years) and shorter experience as compared to those with longer teaching experience.

Table 3 Participation (\%) in different types of CPD activities at least every year (every semester for Reading) among female and male vocational teachers

\begin{tabular}{|c|c|c|c|c|c|c|c|c|}
\hline \multirow[t]{2}{*}{ Sex } & \multicolumn{3}{|c|}{ Relation to work life through: } & \multicolumn{3}{|c|}{ Vocational learning through: } & \multicolumn{2}{|c|}{ Development activities: } \\
\hline & Work & $\begin{array}{l}\text { Study } \\
\text { visits }\end{array}$ & $\begin{array}{l}\text { Students' } \\
\text { placements }\end{array}$ & $\begin{array}{l}\text { Industry } \\
\text { arrangements }\end{array}$ & Studying & $\begin{array}{l}\text { Reading } \\
\text { (semester) }\end{array}$ & Projects & $\begin{array}{l}\text { Pedagogical } \\
\text { improvement }\end{array}$ \\
\hline Female & 57.9 & 86.8 & 83.1 & 66.0 & 25.9 & 84.7 & 45.7 & 65.3 \\
\hline Male & 62.3 & 85.9 & 78.5 & 62.1 & 19.8 & 76.6 & 40.5 & 71.1 \\
\hline All & 60.2 & 86.3 & 80.8 & 64.0 & 22.8 & 80.6 & 43.1 & 68.2 \\
\hline Significance & & & + & & $*$ & $* *$ & & + \\
\hline $\mathrm{N}$ valid cases & 791 & 797 & 791 & 789 & 776 & 789 & 785 & 793 \\
\hline
\end{tabular}

Significant differences in participation in each type of activity between female and male vocational teachers identified through chi-square tests are indicated: $* * p<.01 ; * \mathrm{p}<.05 ;+\mathrm{p}<0.1$ 


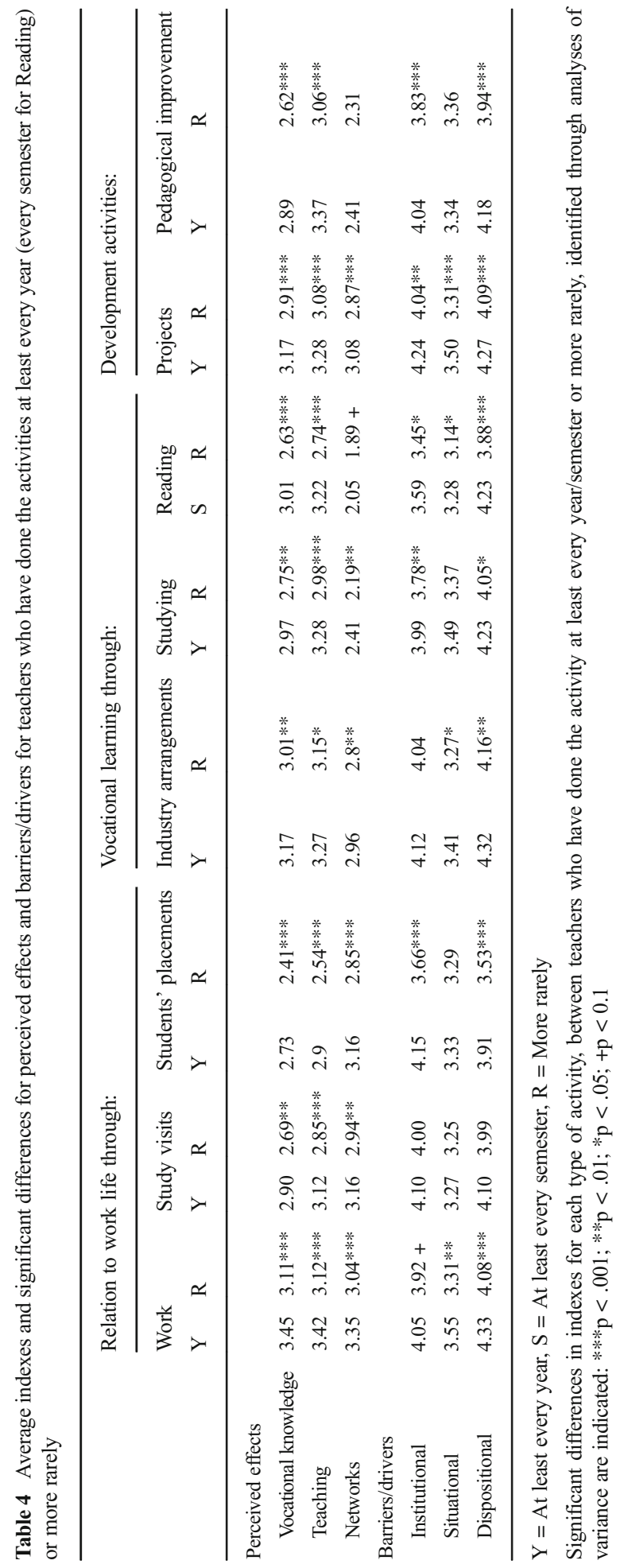




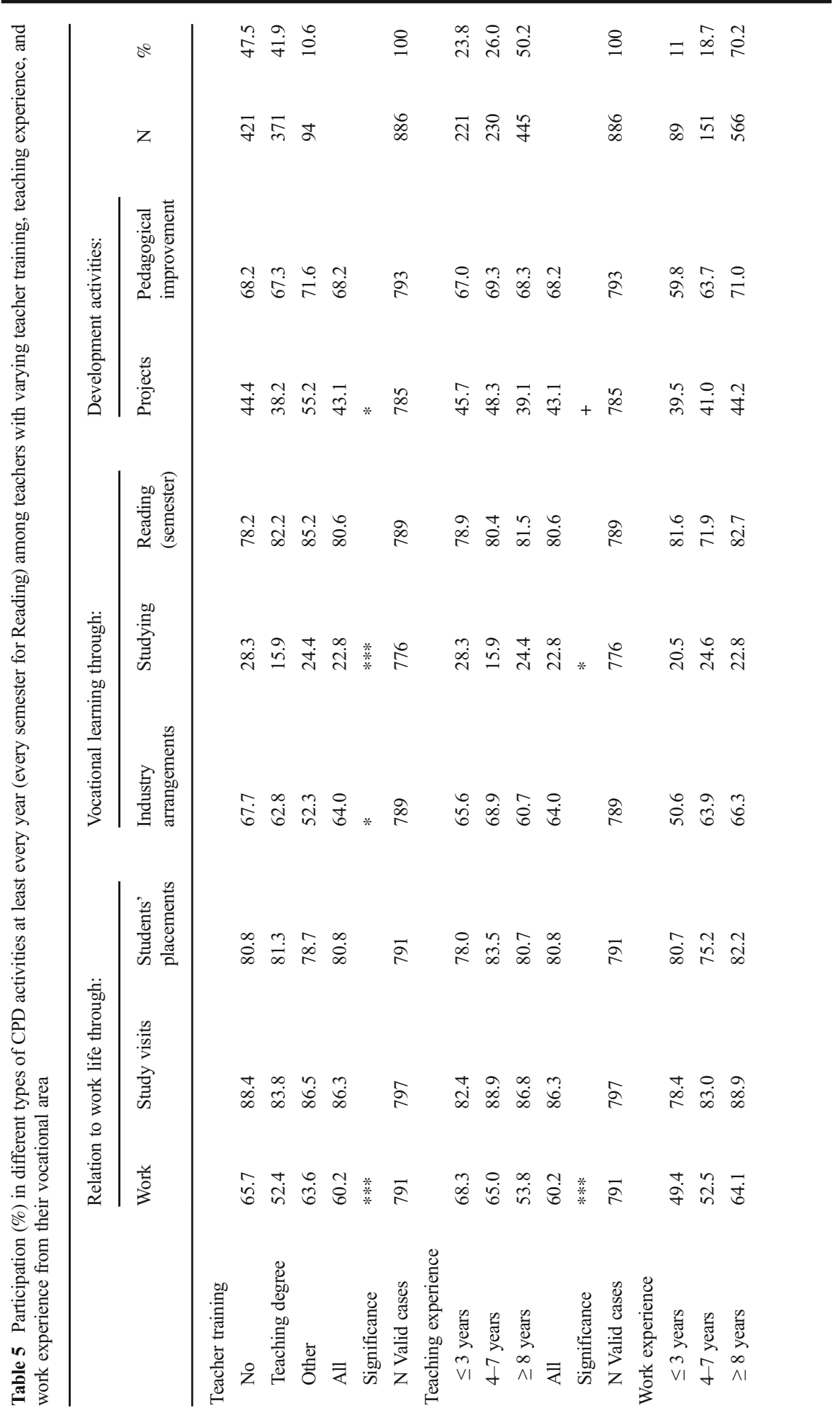




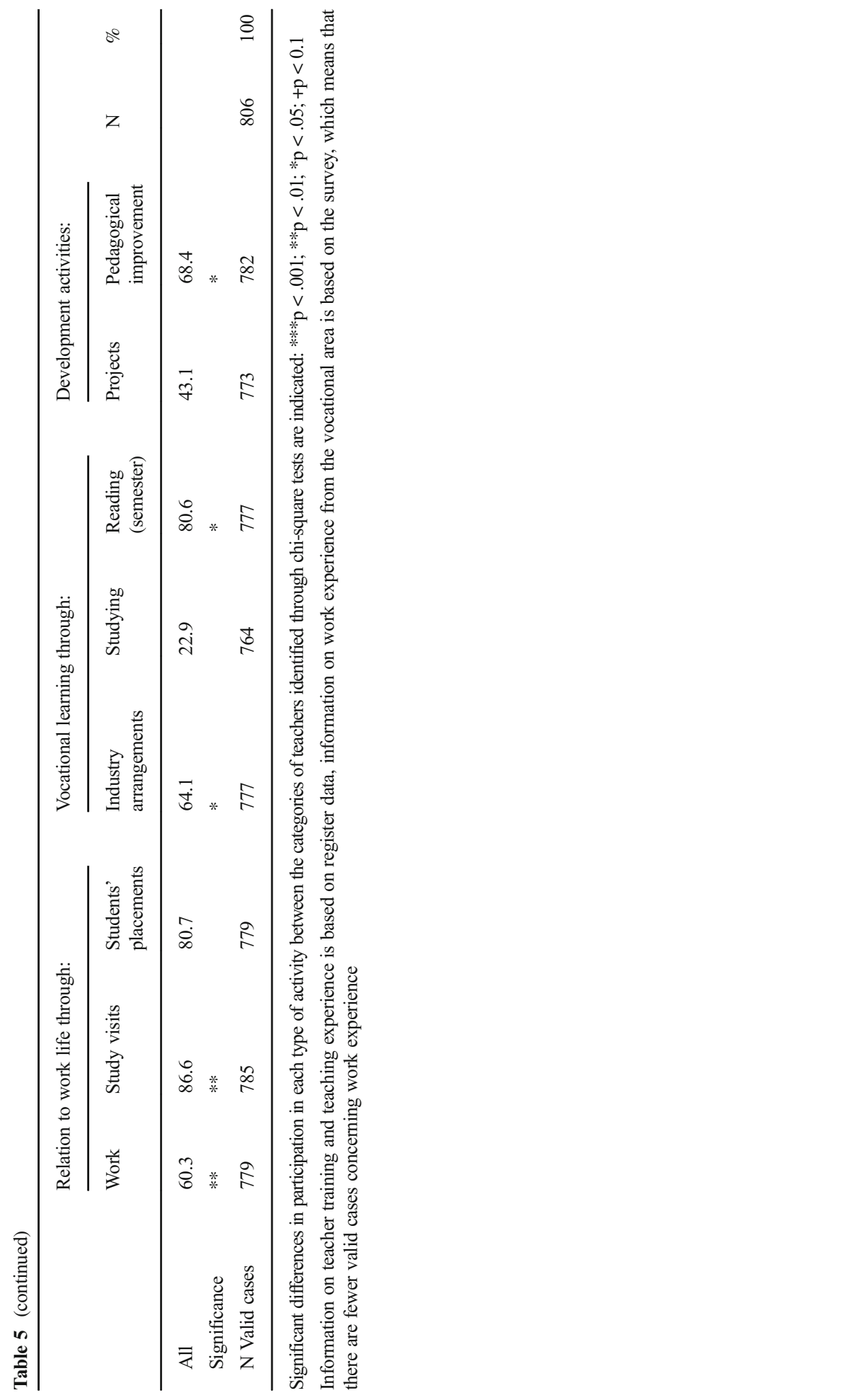


Concerning work experience from the initial occupation, the pattern is the other way around. There are significant differences concerning Work, Study Visits, Industry Arrangements, Reading, and Pedagogical Improvement, and all these activities are performed to a higher degree among teachers with longer experience from the initial occupation. However, concerning Reading, it is those with 4-7 years' experience from the initial occupation that read relevant texts to the lowest degree, while those with shorter and longer experience read more.

We have also included institution-related background variables in the analysis: type of education, employment status, and extent of employment (Table 6) all relate to the practices where the teachers are employed. There is not much difference in participation between teachers from upper secondary school and adult education. The only significant difference is that teachers in upper secondary school arrange more study visits. This could be related to the institutional conditions, with variation between the practice of the two types of schools in terms of time available, and organisation in three-year programmes, and shorter programmes or separate courses. There is also a weak significance $(p<0.1)$ for the higher participation rate in Industry Arrangements and Pedagogical Improvement among teachers in adult education.

The differences between teachers with permanent employment and fixedterm contracts concern teachers' own studying, and work with students' placements. Teachers with fixed-term contracts study to a significantly higher degree, while work with placements is more often a task for permanently employed teachers.

When we look at the influence of the extent of employment, Work in the practice of the initial occupation is, not surprisingly, more common among teachers with a lower extent of employment as teachers (and thus more time for other types of work). Furthermore, participation in Industry Arrangements is also more common among those with a lower extent of employment as teachers. This could indicate a closer relation to the industry/trade among those who work less as teachers and more in the initial occupation. Finally there are significant differences concerning Reading. However, the relation has no linear character. The teachers that read more often are those with the lowest extent of employment, which could indicate that reading vocationrelated texts is part of a closer relation to the industry too. However, those with a higher extent of employment as teachers, but who do not teach full-time, also read more often. The latter difference might be more related to institutional conditions for working as a teacher, where teachers who work full-time have less time for an activity of this type.

There are some differences in participation between teachers from different types of municipalities (Table 7). However, there are no differences that are significant $(p<0.05)$, although there are indications of weak significance $(p<0.1)$ that are of interest. The differences concerning study visits are close to significant, and show that these are more common the smaller the municipality is. Thus, there seems to be a closer relation to the industry practices, which makes it easier to arrange study visits in the small, sparsely populated municipalities. The differences concerning the other activity with an indication of weak significance is more difficult to interpret - teachers in highly populated municipalities seem to do development projects with industry representatives to a lower degree than teachers in larger cities and in sparsely populated municipalities. 


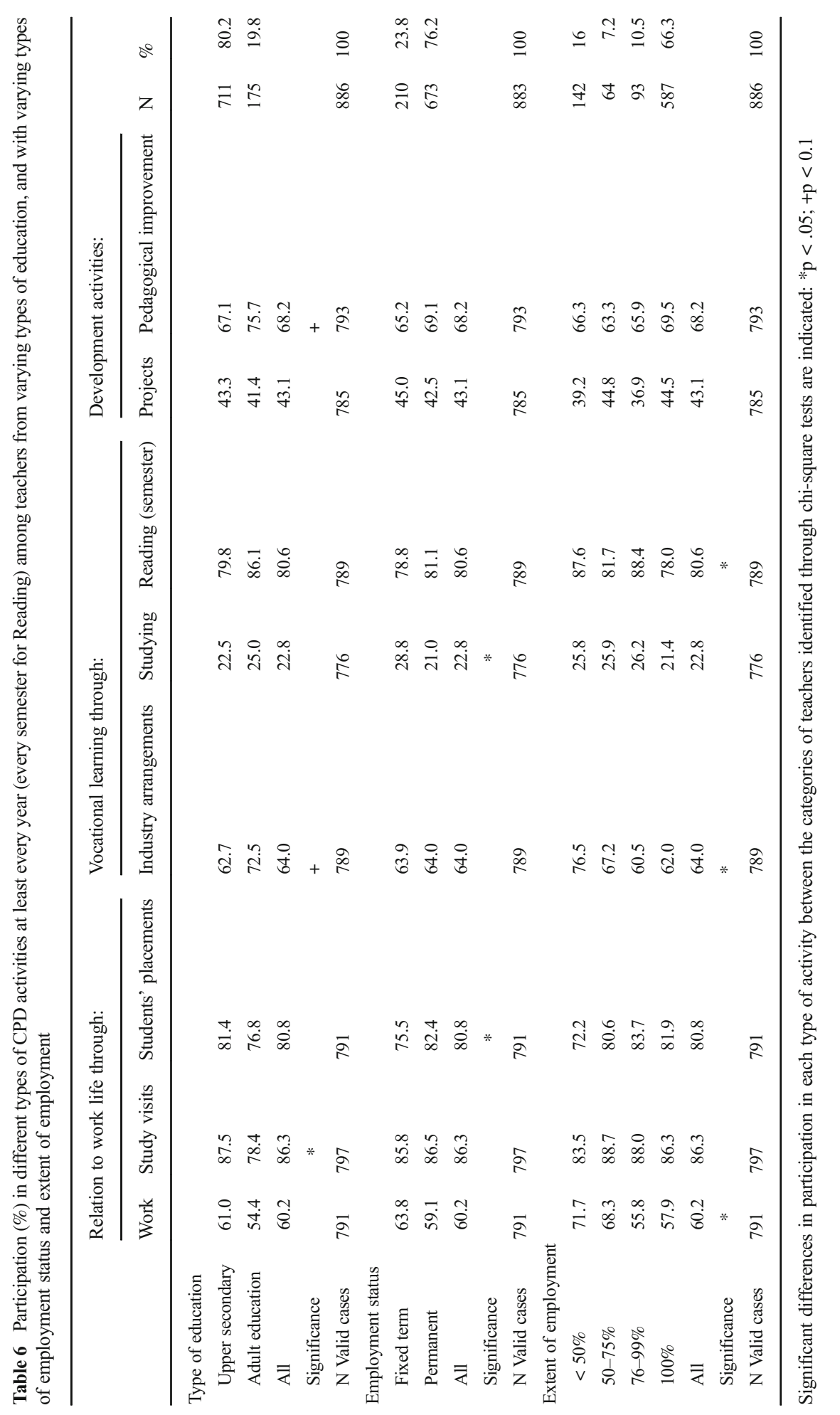




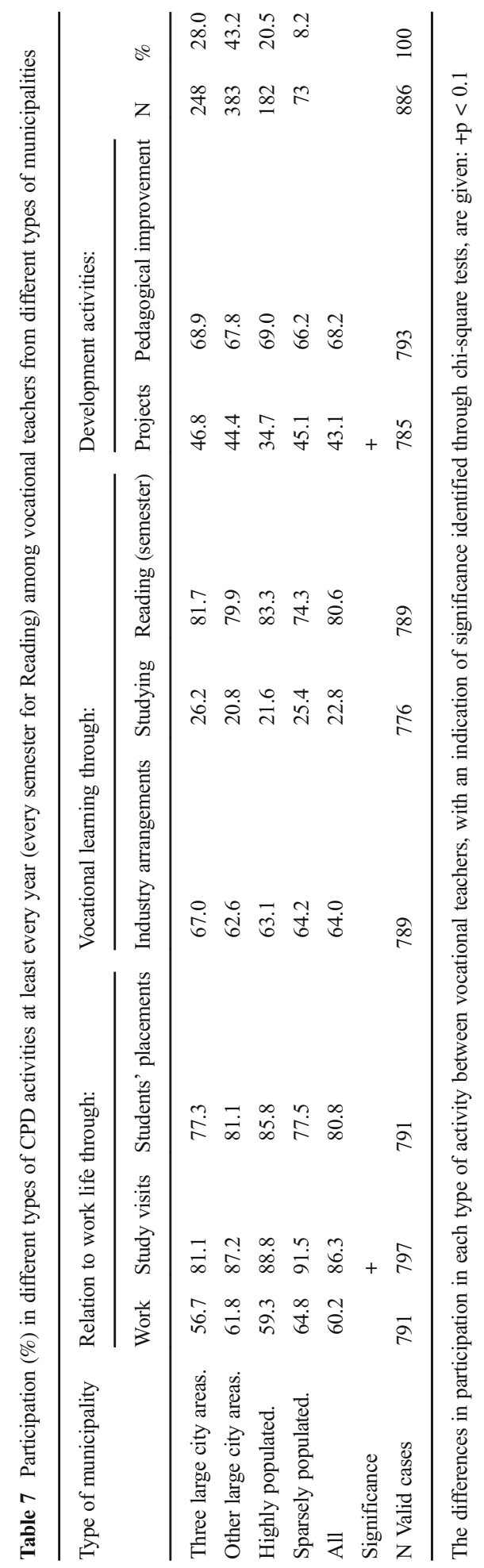


To sum up the findings on the participation in different CPD activities in relation to vocational areas as well as findings on other factors that explain participation in these CPD activities, we noted particularly that:

- Reading and Study Visits are the most common activities.

- Technology teachers engage in CPD activities to a lower degree, and practicalaesthetical teachers do so to a higher degree, than other VET teachers.

- Female VET teachers study and read more than male VET teachers.

- Indexes for perceived effects and drivers/barriers are generally higher for those who have carried out the respective activity regularly than for those who have performed it more rarely.

- Teachers with a teaching degree engage in work and studying to a lower degree than other teachers.

- Teachers with longer teaching experience do less work and studying.

- Teachers with longer work experience work, arrange study visits, and participate in industry arrangements more frequently - activities clearly related to the practice of the initial occupation.

- Teachers with fixed-term contracts study more.

These results have provided answers to our first two research questions concerning the extent of participation in CPD activities, and variation between vocational areas. Furthermore, the results are the basis for the last part of this section, where we will answer the third research question on the extent to which the different variables can explain VET teachers' participation in CPD activities.

\section{The Likelihood of Participating in Different Activities}

Finally, we are identifying what factors have an influence on participating in or performing the different activities when controlling for the influence of other factors. The findings from the logistic regression analyses are presented in terms of adjusted odds ratios $[\operatorname{Exp}(B)]$. In the models applied in the analyses, we have included all variables that had a significant influence on at least one of the activities and that have been described above. The exception is vocational areas that were excluded from the models, even though one of the six areas had a significant influence on one of the activities. Thereafter, sex turned out to have no significant influence in the remaining models, and therefore this variable was also omitted. However, it should be noted that sex had one significant influence in the models including vocational areas, namely on the activity Work in the initial occupation $(\operatorname{Exp}(B)=2.11$ for male vs. female teachers, $p<0.01)$.

The models (Table 8) explain some of the variation in participation in the different activities. The best models are those for the activities Work and Reading. Concerning the boundary crossing activity work in the teachers' initial occupation, there are a number of variables/categories that have significant influence. There is particular influence from the length of the experience as a teacher as well as from the initial occupation, where a shorter teaching experience and a longer work experience mean more work in the initial occupation now. Furthermore, the influence of the perceived effect on the vocational knowledge is reasonable, as is the influence of the extent of 


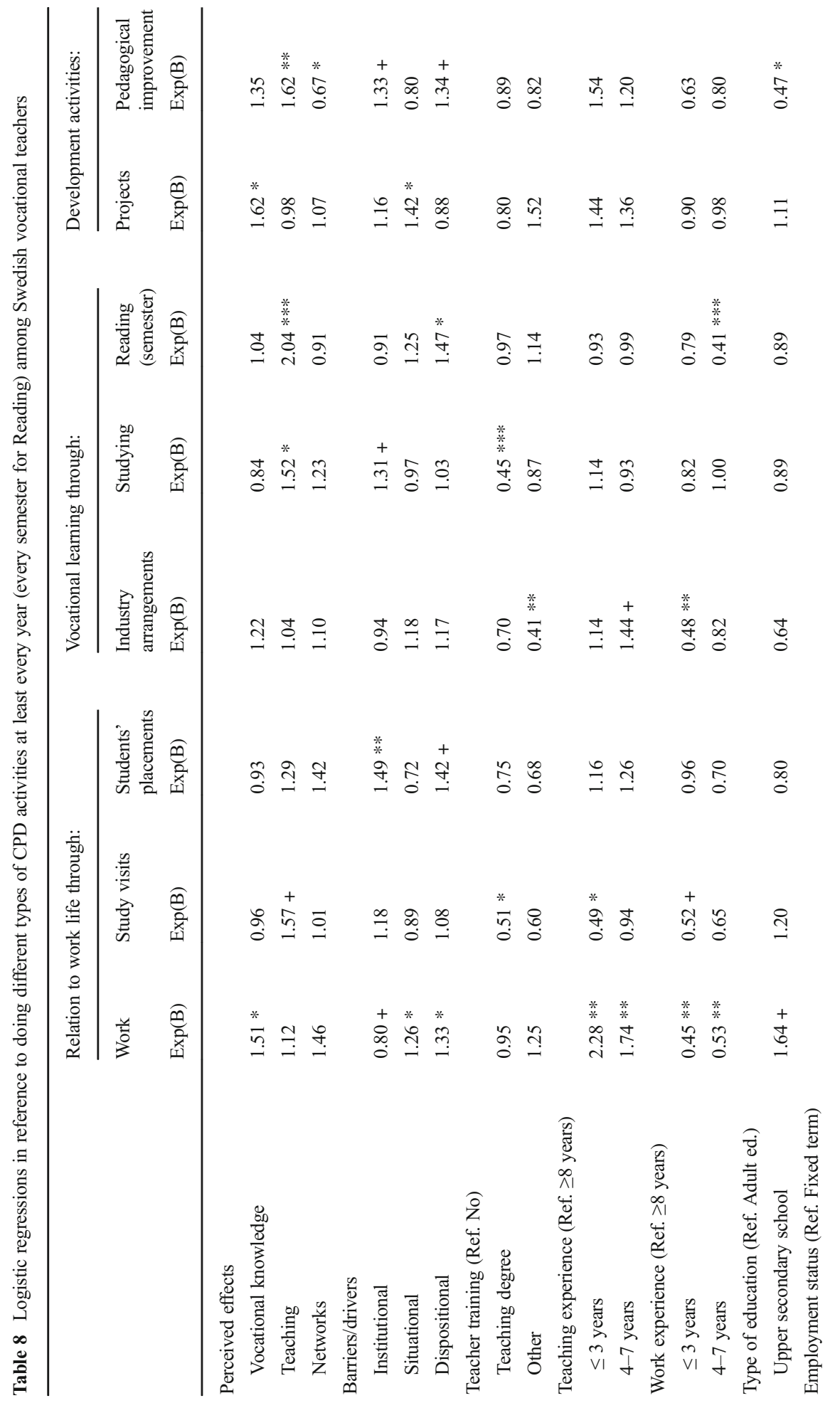




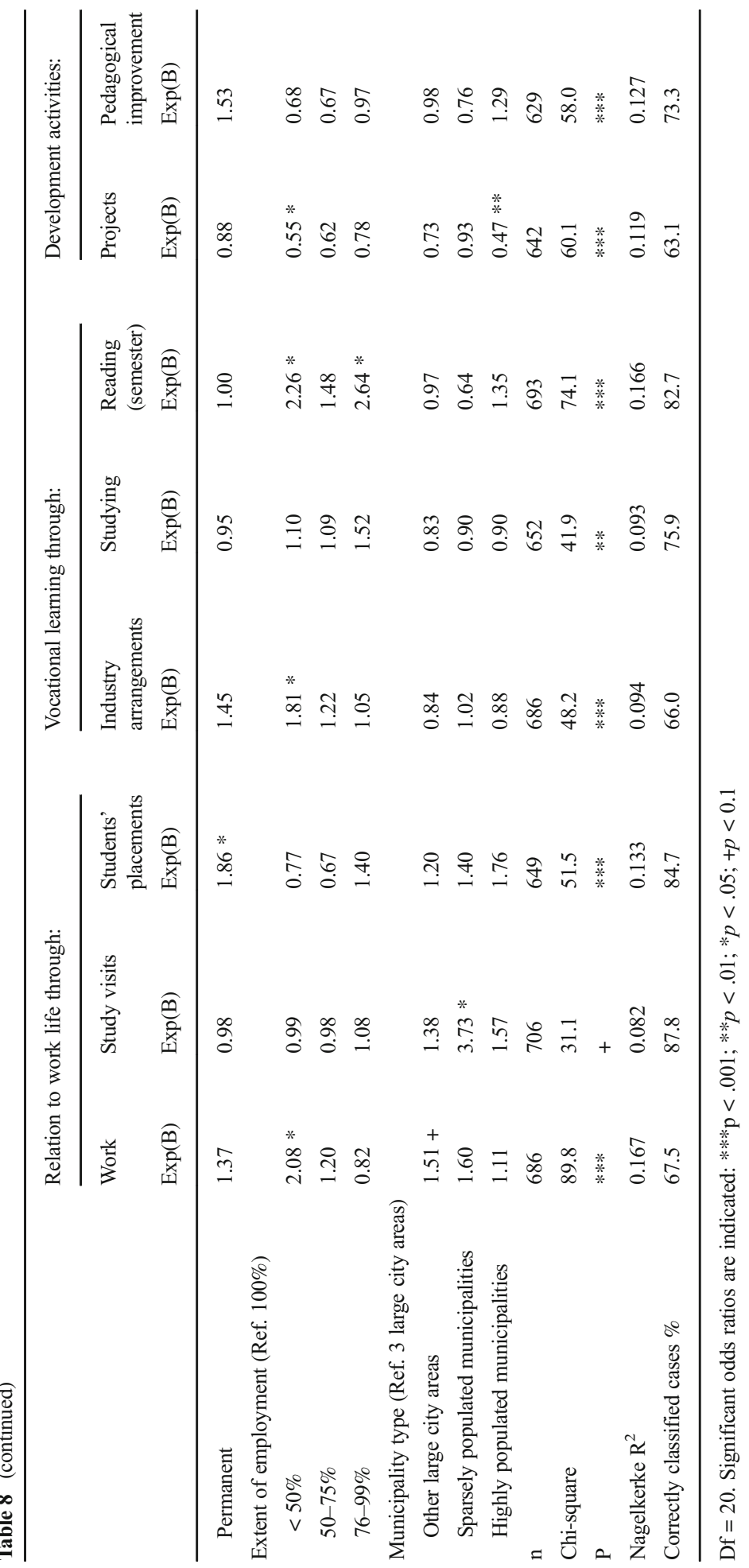


employment as a teacher (more time for other work with less teaching). We can also see that the situational and dispositional factors have a significant influence here.

The factors that have an influence on Reading are somewhat contradictory and more difficult to interpret. Teachers with the lowest extent of employment as well as those employed almost full-time, are most likely to read vocational texts. Among the drivers, the dispositional factor has a significant influence on reading. The influence of the length of work experience from the initial occupation means that those teachers with the longest experience read the most. However, the significant difference is between teachers with the longest experience and those with a medium-long experience. Furthermore, the significant influence of perceived effects concerns the effects on teaching.

Some other activities show comparably good models with a higher degree of explanation than the rest of the activities. Teachers' work with students' placements is influenced particularly by the institutional drivers, but there is also a weak indication of an influence by dispositional factors. Furthermore, the teacher's type of employment has a significant influence - permanently employed teachers are more likely to perform this type of work task. Performing pedagogical improvement also shows a rather high degree of explanation. The most significant influence is from the perceived effect on teaching, which seems reasonable. There is also a negative influence from a perceived effect on networks - the focus of the items included in this index was the network in the vocational area, and pedagogical improvement is probably something that is seen as school-related and conducted internally in the practice of school. As a comparison, we can see - even if the influences are not significant - that Work in the initial occupation and arranging students' placements, activities closely related to the work places and the vocational communities, show the highest odds ratios on this factor. Finally, concerning pedagogical improvement, this activity is more common among teachers in adult education, compared to those in upper secondary school, and there is a weak significance for the institutional and dispositional drivers. There are also some interesting influences on doing development projects. The activity was described in the wording of the question as carrying out such projects with industry representatives, and here we can see a significant influence of the perceived effect on vocational knowledge. There is also a significant positive influence from the situational factor, and a negative influence from a low extent of employment as a teacher. We can also note that there is a negative influence on doing development projects among teachers from highly populated municipalities.

Concerning the remaining activities, teachers with a lower extent of employment as teachers, teachers with longer experience from the initial occupation, and teachers without educational training, participate in industry arrangements to a higher degree - in all cases indicating that teachers who are closer to the industry practices are more likely to participate. The activity of Studying seems to have been interpreted as not only studying related to the initial occupation but also that related to the work as a teacher. The highly significant influence from already having teacher training on non-participation in studying indicates this, as does the positive influence from the perceived effect on teaching. Finally, the significance for the model concerning arranging study visits is low, but one significant factor could be mentioned: teachers in sparsely populated municipalities seem to be much more likely to arrange study visits. 
To summarise the findings of the likelihood of participation in different activities, it is noticeable that:

- Work and Reading are the activities where participation could be explained to the highest degree.

- Longer work experience from the initial occupation means a higher likelihood of doing such work now, while longer teaching experience means a lower likelihood of working in that occupation now.

- A higher perceived effect on vocational knowledge means a higher likelihood of doing work, while a higher perceived effect on teaching means a higher likelihood of reading vocational texts.

- Permanently employed teachers are more likely to work with students' placements, and generally the institutional factors are important for doing this work task.

- Teachers who already have a teaching degree are less likely to study.

\section{Discussions}

The aim of this article is to analyse VET teachers' participation in different activities to develop vocational knowledge with industry currency and, thus, currency for today's VET teaching. The study provides more detailed findings on this topic from a large, representative sample, as compared to Broad's (2016) similar study that was based on a small sample of teachers. The findings show the variation between activities, with Reading and Study Visits as the most common activities. There are more or less significant differences in participation between vocational areas. However, in the logistic regression analyses there are other variables that explain participation to the extent that there is almost no significant influence from the vocational area. Neither is there much difference between female and male teachers, with significant differences only for Reading and Studying. Furthermore, the differences are not reflected in the regression analyses - but there was another significant difference identified for the activity Work in the initial analysis including vocational areas, which showed that male teachers work more in their initial occupations.

The differences concerning perceived effects indicate that the measures of effects are reasonable - it is more likely that those who see valuable effects of an activity will repeat it more often. Another indication from the analysis of the indexes is that the institutional, situational, and dispositional factors - as operationalized in survey items have been interpreted as drivers with a positive influence rather than as barriers to the activities. To sum up, the effects are described as higher and the driving forces as stronger among those who have performed the activities more regularly.

\section{CPD Activities as Boundary Crossing}

There are interesting patterns when it comes to performing different activities, in relation to what we understand as boundary crossings between the community of practice of school and the teacher's initial occupation. The variation in participation in the different communities could also explain the variation in emphasising the different sides of the VET teacher's dual identity (cf. Fejes and Köpsén 2014). The findings clearly 
show that it is more likely that teachers who still have a legitimate membership (Lave and Wenger 1991) in the community of the initial occupation also do work there, parallel to the work as a teacher. Notably, we can see that shorter teaching experience, and longer experience from the work-life outside school, can explain a higher degree of the activity Work.

Most vocational teachers have a background in the initial occupation they teach about, and a shorter teaching experience could mean that they recently left this former occupation - making boundary crossing for work in that occupational community more likely. On the other hand, a shorter period of experience of the initial occupation would mean a less developed occupational identity, making it less likely a person would return to that work community. In other words, longer experience in the initial occupation means that the teacher has 'deeper roots' in that community of practice and is more likely to return there, and a shorter teaching experience means that the teacher is still not that far from the practice of work.

Furthermore, and not surprisingly, teachers with a lower extent of employment as teachers do work in the initial occupation to a higher degree (cf. Lloyd and Payne 2012). This institutionally influenced, but on the individual level situational, factor (cf. Cross 1981), the teachers' extent of employment, constitutes a condition for them to cross the boundary between the two communities of practice regularly and combine the occupation as a teacher with their initial occupation.

Finally, there are differences between vocational areas, even if these are not identified as significant in the regression analyses. It should be noted that the significantly lower participation rates concerning Work and Industry Arrangements among technology teachers reflect findings from Andersson and Köpsén (2015), who identified the same pattern in a targeted national initiative. There seem to be factors in the technology area that influence teachers' opportunities for these types of CPD. The significantly higher participation rate in Industry Arrangements among construction teachers is more surprising in relation to the national initiative, where this category of teachers generally participated to a lower degree (ibid.). However, their participation in Industry Arrangements was higher, which to some extent explains the present findings. A possible interpretation is that construction teachers in general might have good opportunities for participation in a variety of industry arrangements, which could reduce the need for a targeted national initiative. These are all examples of institutional, system-level factors that influence VET teachers' CPD (cf. Bolam and McMahan 2004; Broad 2015), and thus their opportunities for maintaining vocational competence with industry currency.

\section{Reading - The most Common Activity}

As in the study by Broad (2016), we found Reading to be the most common activity, and one where we also could explain 'participation' to a comparably high degree. Reading seems to be a way to become sufficiently up-to-date on teaching the vocation, but not to obtain proper vocational knowledge per se. The teachers probably also include their actual skills in the latter. In other words, reading is insufficient to obtain all the knowledge and skills needed to have full membership and proficiently participate in a community of a vocational practice. Referring to Lave and Wenger (1991) the situated character of knowledge requires participation in the specific community of practice in which learning is integrated in the everyday 
activities. Reading is an example of CPD activity that is not necessarily conducted in the community of the specific occupational practice but that will still contribute to the development of knowledge related to the vocational subject (cf. Wenger-Trayner et al. 2015). Books, professional journals, and magazines can be seen as artefacts that contribute to such transfer of knowledge from work-life to school (cf. Broad 2016).

The pattern identified in the descriptive findings, with more reading among teachers with just below full-time teacher employment, as well as those with less than $50 \%$ employment, is significant even in the regression analysis. The interpretation of the descriptive findings still seems reasonable, particularly when the influence of the perceived effect on teaching is identified in the model - teachers who do not work full-time have time for reading to keep themselves up-to-date, and teachers who work less than $50 \%$ as teachers are probably also working in the initial occupation and have to be up-to-date for that reason too. The influence of the dispositional factor on reading is also reasonable, as compared to the non-significant influence of the institutional and situational factors - reading is something that can be done rather independently of conditions in the institution or life situation. Here, it is noticeable that teachers in the area of care read more than other teachers and care is the area where it is most common that vocational teachers have initial training on a tertiary level, such as nurses teaching in health care or pre-school teachers teaching in child care.

The influence on Reading of the length of work experience in the initial occupation also indicates that the teachers with the longest experience are closer to their old vocation - reading to be up-to-date in the vocation seems a reasonable way of keeping the connection. However, why there is a significant difference between teachers with the longest experience and those with medium-long experience remains to be determined.

\section{Different Institutional Conditions Depending on Local Practices?}

There are also patterns that are worth mentioning concerning the geographical dimension. The prior studies of CPD among Swedish vocational teachers showed that teachers from highly populated municipalities were overrepresented among participants in a national initiative (Andersson and Köpsén 2015), and that the geographical dimension was the strongest predictor for recurrent participation (Köpsén and Andersson 2017). In the present analysis, there is a negative influence on doing development projects among teachers from highly populated municipalities. Are there institutional conditions in the local VET practices of these municipalities that could explain such influence? Are the networks with industry representatives weaker here than in other municipalities? On the other hand, teachers in sparsely populated municipalities seem to be more likely to arrange study visits in work-life practices, which is an indication of the importance of networks and close connections to the industry - and it is more likely that teachers would have such connections in a small town than in a large city. These conditions call for a holistic view of VET teachers' CPD activities (cf. Day and Sachs 2004), and for further investigation of factors influencing boundary crossing and performance of other activities providing CPD experiences. 


\section{Conclusions}

From the findings and the discussions above, we conclude that:

- Vocational teachers' participation in CPD activities is influenced by their background in relation to different communities of practice, and conditions for boundary crossing between these practices - between school, work-life, and other boundary practices where teachers themselves are intended to study and learn. Legitimate membership in the community of the initial occupation is particularly important for participation in activities closely related to this community.

- Reading is an activity related to work both in the initial occupation and as a teacher. However, even if this is the most common activity, full-time employment as a vocational teacher seems to be a barrier to reading professional and industrial texts related to the vocational subject.

- The local, geographical conditions have an influence on some types of activities where boundary crossing between practices of school and worklife is crucial.

For VET teachers across vocational areas it is crucial to maintain vocational competence with industry currency. This is particularly important in systems with a high degree of school-based learning and teacher responsibility for students' vocational learning. Our study has described participation in activities that help the teachers in this CPD process. We have also identified factors that influence such participation, and based on our theoretical perspective we have highlighted the central role of activities that involve boundary crossing between school and work-life. Even if an activity such as reading texts is common and could help in developing knowledge, participation in work-life as well as networking with former colleagues from the initial occupation is vital for currency. Thus, VET teachers' opportunities for participation in and relations with the practices of work-life - but also local conditions and needs - should be considered in the development of these teachers' CPD. The study has also shown the importance of teachers' background in relation to drivers and barriers to the boundary crossing between school and work-life. Such boundary crossing is crucial for this type of CPD. The 'distance' to the practice of the initial occupation seems to be important, where teachers with long experience from the initial occupation, and shorter teaching experience, are closer to the occupational practice, i.e. have stronger networks (cf. Broad 2015), and are more likely to cross the boundaries. Thus, more efforts are needed to enhance CPD among teachers who are more 'distant' from their initial occupational practices and have weaker networks.

For a broader picture of vocational teachers' CPD, it will be valuable to obtain more extensive descriptions of their own experiences. As mentioned above, a qualitative interview study is the next step in the larger project of which the present study is one part. The interview study is expected to result in a deeper understanding of the way in which professional development in 
relation to the initial occupation is or is not part of the professional life of vocational teachers, and what this means for the development of teaching in VET.

Funding This study was funded by the Swedish Research Council.

\section{Compliance with Ethical Standards}

Conflicts of Interest The authors declare that they have no conflicts of interest.

Open Access This article is distributed under the terms of the Creative Commons Attribution 4.0 International License (http://creativecommons.org/licenses/by/4.0/), which permits unrestricted use, distribution, and reproduction in any medium, provided you give appropriate credit to the original author(s) and the source, provide a link to the Creative Commons license, and indicate if changes were made.

\section{References}

Akkerman, S. F., \& Bakker, A. (2011). Boundary crossing and boundary objects. Review of Educational Research, 81(2), 132-169.

Andersson, P., \& Köpsén, S. (2015). Continuing professional development of vocational teachers: participation in a Swedish national initiative. Empirical Research in Vocational Education and Training, 7(7), 120.

Berner, B. (2010). Crossing boundaries and maintaining differences between school and industry: forms of boundary-work in Swedish vocational education. Journal of Education and Work, 23(1), 27-42.

Billett, S. (2011). Vocational education: purposes, traditions and prospects. New York: Springer.

Bolam, R. \&, McMahan, A. (2004). Literature, definitions and models: towards a conceptual map. In C. Day \& J. Sachs (Eds.), International handbook on the continuing professional development of teachers (pp. 33-63). Maidenhead: Open University Press.

Bound, H. (2011). Vocational education and training teacher professional development: tensions and context. Studies in Continuing Education, 33(2), 107-119.

Broad, J. H. (2013). Doing it for themselves: a network analysis of vocational teachers' development of their occupationally specific expertise. EdD thesis. London: Institute of Education, University of London.

Broad, J. H. (2015). So many worlds, so much to do: identifying barriers to engagement with continued professional development for teachers in the further education and training sector. London Review of Education, 13(1), 16-30.

Broad, J. H. (2016). Vocational knowledge in motion: rethinking vocational knowledge through vocational teachers' professional development. Journal of Vocational Education \& Training, 68(2), 143-160.

Brockmann, M., Clarke, L., Méhaut, P., \& Winch, C. (2008a). Competence-based vocational education and training (VET): the cases of England and France in a European perspective. Vocations and Learning, 1, 227-244.

Brockmann, M., Clarke, L., \& Winch, C. (2008b). Knowledge, skills, competence: European divergences in vocational, education and training (VET) - the English, German and Dutch cases. Oxford Review of Education, 34(5), 547-567.

Cross, K. P. (1981). Adults as learners. San Francisco: Jossey-Bass.

Day, C., \& Sachs, J. (2004). Professionalism, performativity and empowerment: discourses in the politics, policies and purposes of continuing professional development. In C. Day \& J. Sachs (Eds.), International handbook on the continuing professional development of teachers (pp. 3-32). Maidenhead: Open University Press.

Farnsworth, V., \& Higham, J. (2012). Teachers who teach their practice: the modulation of hybridised professional teacher identities in work-related educational programmes in Canada. Journal of Education and Work, 25(4), 473-505. 
Fejes, A., \& Köpsén, S. (2014). Vocational teachers' identity formation through boundary crossing. Journal of Education and Work, 27(3), 265-283.

Frisk, T. (2014). Guide for the implementation of vocational teachers' work placement periods. The Finnish National Board of Education: Helsinki.

Grollmann, P. (2008). The quality of vocational teachers: teacher education, institutional roles and professional reality. European Educational Research Journal, 7(4), 535-547.

Hoekstra, A., \& Crocker, J. R. (2015). ePortfolios: enhancing professional learning of vocational educators. Vocations and Learning, 8(3), 353-372.

Köpsén, S. (2014). How vocational teachers describe their vocational teacher identity. Journal of Vocational Education \& Training, 66(2), 194-211.

Köpsén, S., \& Andersson, P. (2017). Reformation of VET and demands on teachers' subject knowledge: Swedish vocational teachers recurrent participation in a national CPD initiative. Journal of Education and Work, 30(1), 69-83.

Lave, J., \& Wenger, E. (1991). Situated learning: legitimate peripheral participation. Cambridge: Cambridge University Press.

Lloyd, C., \& Payne, J. (2012). Raising the quality of vocational teachers: continuing professional development in England, Wales and Norway. Research Papers in Education, 27(1), 1-18.

Messmann, G., \& Mulder, R. H. (2011). Innovative work behaviour in vocational colleges: understanding how and why innovations are developed. Vocations and Learning, 4(1), 63-84.

Ministry of Education (2009). Prop 2008/09:199 Högre krav och kvalitet i den nya gymnasieskolan [higher demands and quality of the new upper secondary school]. Stockholm: Utbildningsdepartementet.

Misra, P. K. (2011). VET teachers in Europe: policies, practices and challenges. Journal of Vocational Education \& Training, 63(1), 27-45.

Opetushallitus (2014). Examensmästare, utbildningsprogram [master of competence-based qualifications, curriculum]. Helsinki: Opetushallitus [Finnish National Board of Education].

Parsons, D., Huges, J., Allincon, C., \& Walsh, K. (2009). The training and development of VET teachers and trainers in Europe. In Cedefop (Ed.), Modernising vocational education and training, fourth report on vocational education and training research in Europe: synthesis report (pp. 71-141). Luxembourg: Publications Office of the European Union.

Robson, J., Bailey, B., \& Larkin, S. (2004). Adding value: investigating the discourse of professionalism adopted by vocational teachers in further education colleges. Journal of Education and Work, 17(2), 183-195.

Statistics Sweden (2011). Regionala indelningar i Sverige den 1 januari 2011 [regional classifications in Sweden 1 January 2011]. Örebro: Statistics Sweden.

Swedish National Agency of Education (2015). Personal i gymnasieskolan läsår 2014/15 [Staff in upper secondary school year 2014/!5]. Accessed 9 June 2017 from https://www.skolverket.se/statistik-ochutvardering/statistik-i-tabeller/gymnasieskola/personal/personal-i-gymnasieskolan-lasar-2014-151.233512 .

Vähäsantanen, K., Saarinen, J., \& Eteläpelto, A. (2009). Between school and working life: vocational teachers' agency in boundary-crossing settings. International Journal of Educational Research, 48(6), 395-404.

Wenger, E. (1998). Communities of practice: learning, meaning, and identity. Cambridge: Cambridge University Press.

Wenger-Trayner, E., Fenton-O'Creevy, M., Hutchinson, S., Kubiak, C., \& Wenger-Trayner, B. (2015). Learning in landscapes of practice: boundaries, identity, and knowledgeability in practice-based learning. Abingdon: Routledge.

Per Andersson is a professor of education at the Department of Behavioural Sciences and Learning at Linköping University, Sweden. His research interests focus on recognition of prior learning, and professional development among teachers in vocational and adult education.

Susanne Köpsén is an associate professor of education at the Department of Behavioural Sciences and Learning at Linköping University, Sweden. Her research concerns supervision and learning in school, work, and associations. At the moment the focus is on vocational education, particularly teaching, teacher identity and the professional development of vocational teachers. 